\title{
JILBER'S SYNDROME: CLINICAL AND PHARMACOLOGICAL ASPECTS. Review
}

\author{
Khaitovych M.V. (https://orcid.org/0000-0001-6412-3243) \\ Turchak D.V. (https://orcid.org/0000-0001-8799-0817) \\ Bogomolets National Medical University, Kyiv, Ukraine \\ nik3061@gmail.com
}

\begin{abstract}
Relevance. At present, the metabolism of drugs in patients with Gilbert's syndrome will be actively studied, as it may be associated with both the risk of dose-dependent adverse reactions and treatment ineffectiveness.

Objective: to summarize the information of various authors on the peculiarities of the use of drugs in patients with Gilbert's syndrome.

Methods. Analysis of scientific publications in the international electronic scientometric database PubMed by keywords. Search depth - 10 years (2010-2019).
\end{abstract}

Results. Gilbert's syndrome is observed in $3-10 \%$ of the population and is characterized by an isolated increase of bilirubin in the blood to moderate values without changes in other biochemical parameters of liver function and without damage to its structure. Gilbert's syndrome is inherited autosomal recessively and is mainly due to the presence of an additional dinucleotide thymine-adenine (TA) in the promoter region A(TA)6TAA gene encoding the enzyme UGT1A1. Elongation of the promoter sequence reduces the formation of UGT1A1. In variant A(TA)7TAA, the level of enzyme production can be reduced to $80 \%$ of the norm in hetero- and up to $20 \%$ in homozygotes, respectively. Gilbert's syndrome is manifested by increased levels of indirect bilirubin in the blood, jaundice of the skin and mucous, abdominal pain, as well as dyspepsia and asthenovegetative syndrome. Intermittent icteric sclera and skin occur against the background of exogenous and endogenous factors such as starvation, dehydration, infectious diseases, emotional and physical stress, hemolysis, menstruation, alcohol consumption, hormonal contraception, etc., usually at a bilirubin concentration exceeding 40-45 $\mu$ mol/1. Complications of hyperbilirubinemia with Gilbert's syndrome include the development of gallstone disease, including in children and adolescents. Gilbert's syndrome is associated with impaired metabolism of some drugs - aglucones. These include anabolic steroids, glucocorticoids, androgens, rifampicin, cimetidine, chloramphenicol, streptomycin, sodium salicylate, ampicillin, caffeine, ethinyl estradiol, paracetamol, ibuprofen, The clinical feature of Gilbert's syndrome is the appearance or aggravation of jaundice associated with the use of such drugs. In conditions of UGT1 deficiency, drugs compete with bilirubin for the enzyme, which leads to an increase of indirect bilirubin in the serum. Therefore, to prevent liver damage, it is necessary to assess the risk and benefit of drug treatment of patients with Gilbert's syndrome in each case.

Conclusions. Gilbert's syndrome is a common pathological condition and therefore it is important to diagnose it as early as possible. Given that the use of aglucones in patients with Gilbert's syndrome may cause the development of drug-induced liver damage, it is necessary to assess the risk and benefit of drug treatment of patients with Gilbert's syndrome in each case.

Key words: Gilbert's syndrome, drugs, metabolism, pharmacogenetics

Relevance. Gilbert's syndrome (GS) was first described in 1901 by the French gastroenterologist Augustin Nicolas Gilbert and is the most common form of hereditary pigmented hepatosis.Gilbert's syndrome is characterized by an isolated increase in the level of bilirubin in the blood to moderate values (in the range of 21-85 $\mu \mathrm{mol} / \mathrm{l})$ without changes in other biochemical parameters of liver function and without damage to its structure [30]. Gilbert's syndrome is observed in 3-10\% of the population [18]. The prevalence of Gilbert's syndrome varies significantly in different countries, which is to some extent due to differences in diagnostic criteria.Gilbert's syndrome is more often diagnosed in boys during puberty than in girls.For men and women, the ratio of Gilbert's syndrome is $2: 1-7: 1$. Pubertal age of onset of the disease is attributed of Inhibition of bilirubin glucuroning by endogenous steroid hormones.It is believed that bilirubin production is higher in men than in women [28].
Currently, in the patients with Gilbert's syndrome continue to actively study the characteristics of drug metabolism, since this may be associated with both the risk of dose-dependent adverse reactions and the ineffectiveness of treatment.

Objective: to summarize the information of various authors on the peculiarities of the use of drugs in patients with Gilbert's syndrome.

\section{METHODS}

Analysis of scientific publications in the international electronic scientometric database PubMed by keywords. Search depth -10 years (2010-2019).

\section{RESULTS}

Etiology and pathogenesis. Hepatic bilirubin metabolism is the most important factor in determining the concentration of bilirubin in the blood of healthy peopleThe disease is based on a violation of bilirubin 
conjugation due to insufficiency $(\leq 40 \%$ of normal activity) of the enzyme uridine-5-diphosphate glucuronosyltransferase (UGT) 1A1 in the liver [15]. This metabolic disorder is caused by a genetic defect in the enzyme UGT1A1 [20].

Leukocytes, including macrophages, are known to remove potentially harmful heme from the extracellular space and to produce heme catabolites, including iron, carbon monoxide, and biliverdin/bilirubin. Approximately $25 \%$ of heme is derived from inefficient erythropoiesis and heme-containing enzymes, and the remaining $75 \%$ from obsolete erythrocytes that are processed in the reticuloendothelial system [34]. In macrophages, heme catabolism is first carried out by hemoxygenase (Fig. 1), with biliverdin being formed, which is then converted to bilirubin (unbound or indirect bilirubin) by biliverdin reductase. Indirect bilirubin is a lipophilic molecule and circulates in the blood plasma mainly in the albumin-bound state [34]. Albumin transports indirect bilirubin to the liver, where it, bound by ligands, diffuses into the cytosol by OATP transporter proteins [1]. In the endoplasmic reticulum, bilirubin is conjugated to mono- and diglucuronide using the UGT1 enzyme. UGT1A1 conjugates glucuronic acid with bilirubin and converts it to water-soluble substances that can be excreted in bile.Bound bilirubin (direct bilirubin) is exported to the bile duct by transporters of the MRP2 family (multiple drug resistance protein-2), and a small amount - by transporters of MRP3 can be excreted through the sinusoidal membrane into the blood [1]. If under physiological conditions MRP expression is at a very low level, then in cholestasis, these transporters begin to be actively expressed [13].

Once in the bile, bilirubin glucuronides are first stored in the gallbladder and then sent to the intestine with other bile components that facilitate the absorption of fats and other fat-soluble compounds.Bilirubin glucuronides are then deconjugated by bacterial $\beta$-glucuronidases, with the unconjugated pigment being reduced and oxidized. Some of these products may be reabsorbed and promote the circulation of the bilirubin pool; others are excreted through the kidneys and intestines and contribute to the color of urine and feces, respectively [1].

Physiological inhibitors of UGT1A1 are the steroid hormones estrogen and testosterone, so they significantly affect the concentration of bilirubin in the blood.

Genetics. Gilbert's syndrome is inherited autosomal recessively. A genetic defect mapped to chromosome 2 at the q37 locus and due to the presence of an additional thymine-adenine (TA) dinucleotide in the promoter region $\mathrm{A}(\mathrm{TA})$ of the 6TAA gene encoding the UGT1A1 enzyme leads to the formation of region A(TA)7TAA [10]. Elongation of the promoter sequence leads to a decrease in the formation of UGT1A1. This mutation is designated UGT1A $1 * 28$ and is the most common and studied.In variant A(TA)7TAA, the level of enzyme production can be reduced to $80 \%$ of the norm in hetero- and up to $20 \%$ in homozygotes, respectively. Clinically, the syndrome is found

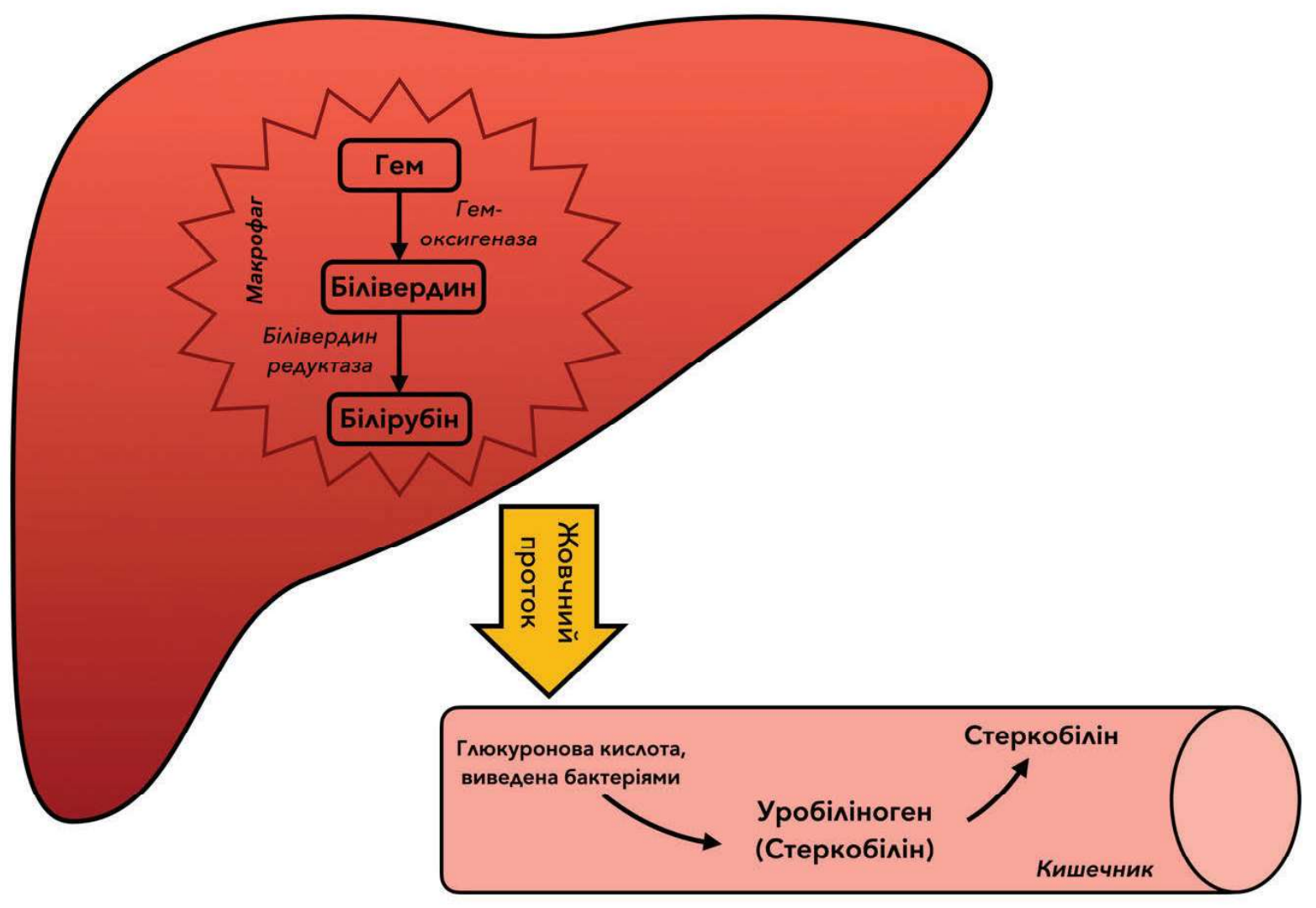

Fig. 1. Heme metabolism 
in carriers of the homozygous state of this mutation, which is found in $11-16 \%$ of the population [17], while in $42 \%$ of the population the condition is heterozygous $[16,23]$. In a study in Romania, 292 patients and 605 healthy people, $62 \%$ of patients showed polymorphism UGT1A1*28 (7TA), about 37\% - UGT1A1*1 (6TA), the remaining $0.61 \%$ and $0.72 \%$, respectively, options $5 \mathrm{TA}$ and $8 \mathrm{TA}$ [24]. About $58 \%$ of the experimental group had a heterozygous genotype (TA)6/7, 32\% - homozygous (TA)7/7 genotype. As a rule, in heterozygous carriers, Gilbert's syndrome does not manifest clinically, however, indirect bilirubin is at the upper limit of the norm or may be slightly elevated.

There are data on the presence of up to 113 variants of mutations of this gene (UGT1A1*1-*113), including 5 exons and introns of the UGT1A1 gene, often in combination with genetic polymorphisms of other UGT1A genes, which are associated with either mild hyperbilirubinemia or lifethreatening jaundice [31]. Recent genetic results indicate a dual genetic polymorphism of UGT 1A6 and 1A1 in patients with Gilbert's syndrome, leading to a defect in bilirubin glucuronidation, as well as other endogenous and exogenous substrates such as serotonin [20].

Clinical manifestations. Gilbert's syndrome is manifested by increased levels of indirect bilirubin in the blood, jaundice of the skin and mucous membranes,abdominal pain, as well as dyspepsia and asthenovegetative syndrome. Intermittent icteric sclera and skin occur against the background of exogenous and endogenous factors,such as starvation, dehydration, infectious diseases (including asymptomatic EpsteinBarr infection), emotional and physical stress, hemolysis or menstruation,alcohol consumption, hormonal contraception, etc. [17,34] usually at a bilirubin concentration exceeding 40-45 $\mu \mathrm{mol} / 1$ [34].

There is evidence of delayed gastric emptying in Gilbert's syndrome, and this is explained, on the one hand, by the fact that gastrointestinal motility may affect the concentration of bilirubin, or by the fact that bilirubin may affect the motility of the gastrointestinal tract. The transit time in the gastrointestinal tract affects the concentration of bilirubin in the blood, prolonging the transit time due to decreased gastric motility during fasting, allows to absorb deconjugated glucuronides of bilirubin by passive diffusion, accompanied by an increase in circulating bilirubin 1.5-2 times [34].

Hyperserotoninemia in Gilbert's syndrome may contribute to nonspecific symptoms [20].

Complications of hyperbilirubinemia with Gilbert's syndrome include the development of gallstone disease. This was confirmed by a meta-analysis that included 2,816 patients with gallstone disease and 1,617 patients without gallstone disease. The study found that the risk of developing gallstones in Gilbert's syndrome increased by $21.2 \%$, more often among men [5]. It should be noted that with Gilbert's syndrome, the development of gallstones can form in childhood. It was found that $76.5 \%$ of children with Gilbert's syndrome had biliary tract dysfunction; almost half of them had sludge syndrome. Gallstone disease was diagnosed in $11.8 \%$ of children [2].

The protective effect of hyperbilirubinemia is described, in particular it is manifested in a reduction in twice the mortality than in the general population [14], due to a reduced risk of diseases associated with oxidative stress [33], in particular cardiovascular diseases and metabolic syndrome [8]. According to the results of a double-blind placebo-controlled study,in which with the help of atazanavir in 16 patients with type 2 diabetes caused moderate hyperbilirubinemia for 3 days (the level of bilirubin increased on average from $7 \mathrm{mmol} / \mathrm{l}$ to $64 \mathrm{mmol} / \mathrm{l}$ ), found a significant improvement in the antioxidant properties of plasma and endotheliumdependent vasodilation, a decrease in blood levels of factor Willebrand [7] with moderate hyperbilirubinemia.

For diagnostic purposes, now patients are determined by the number of TA repeats in the promoter region of the UGT1A1 gene, normally they are 6 . An increase in the number of repetitions in this area indicates a decrease in the functional activity of UGT1A1. A test with a lowcalorie diet is also performed for diagnostic purposes (400 $\mathrm{kcal} /$ day for 3 days) with the subsequent appointment of phenobarbital $(0.1 \mathrm{~g} /$ day at night for a week). The test with a low-calorie diet is evaluated by the percentage of patients, who responded by increasing the concentration of bilirubin by $21.4 \mu \mathrm{mol} / \mathrm{l}$, the test with phenobarbital is considered positive, if the level of bilirubin decreases more than 3 times from its values after a test with a lowcalorie diet.

Clinical and pharmacological aspects of Gilbert's syndrome. It is known that metabolism (biotransformation) is a change in the chemical structure of medicinal preparation and their physicochemical properties under the action of enzymes in the body. The metabolism of medicinal preparation includes 2 phases: phase I or chemical modification involving mainly cytochrome P450 isoenzymes, phase II or conjugation reactions with glucuronic, sulfuric, acetic acid or amino acids.

Gilbert's syndrome has been shown to be associated with impaired metabolism of some medicinal preparation (Table.1) [25]. The clinical feature of Gilbert's syndrome is the appearance or worsening of jaundice associated with medication. In conditions of UGT1 deficiency, drugs compete with bilirubin for the enzyme,leading to an increase in indirect serum bilirubin. Such drugs are called aglucones. These include anabolic steroids, glucocorticoids, androgens, rifampicin, cimetidine, chloramphenicol, streptomycin, sodium salicylate, ampicillin, caffeine, ethinyl estradiol, paracetamol, ibuprofen,ketoprofen, sulfonamides, diacarb, menthol, statins, etc. [30]. Thus, the use of paracetamol, irinotecan, atazanavir or elvitegravir in patients with Gilbert's syndrome may be associated with frequent adverse side effects of pharmacotherapy [31]. 
Medicines that are metabolized by glucuronidation

\begin{tabular}{|l|l|}
\hline \multicolumn{1}{|c|}{ Medicines } & \multicolumn{1}{c|}{ Clinical application } \\
\hline Tolbutamide & Type 2 diabetes \\
\hline Amidopyrine & $\begin{array}{l}\text { Inflammation, fever, } \\
\text { pain }\end{array}$ \\
\hline Menthol & Pain as a decongestant \\
\hline Estradiol & $\begin{array}{l}\text { Menopause, prostate } \\
\text { cancer }\end{array}$ \\
\hline Lamotrigine & $\begin{array}{l}\text { Epilepsy, bipolar } \\
\text { disorder }\end{array}$ \\
\hline Tricyclic antidepressants & $\begin{array}{l}\text { Depression, neuropathic } \\
\text { pain }\end{array}$ \\
\hline Irinotecan & Colorectal cancer \\
\hline $\begin{array}{l}\text { Nonsteroidal anti-inflammatory } \\
\text { drugs }\end{array}$ & $\begin{array}{l}\text { Inflammation, fever, } \\
\text { pain }\end{array}$ \\
\hline Paracetamol & Fever, pain \\
\hline HIV protease inhibitors & HIV \\
\hline
\end{tabular}

Back in 1999, 2 heterogeneous groups of patients with Gilbert's syndrome were described, depending on the metabolism of paracetamol. In one group he was normal,whereas in the other glucuronidation was less than $50 \%$. Decreased glucuronidation was combined with increased oxidation, which contributed to the formation of the toxic metabolite paracetamol [9]. Subsequently, the results of a number of studies did not reveal features of paracetamol metabolism in patients with Gilbert's syndrome, which led the authors to believe that paracetamol is a substrate of another isoform of UGT [26]. It is now known that paracetamol is metabolized by isoenzymes UGT1A1, UGT1A6 and UGT1A9, therefore, the results of modern studies indicate that paracetamol is safe for patients with the Gilbert's syndrome in normal doses [22].

It should be noted that toxic metabolites of some drugs can cause the development of hyperbilirubinemia with intrahepatic cholestasis due to damage to carrier proteins of the BSEP (bilesaltexportpump) family, exporting bile acids, or transporter proteins of the MRP2 family, involved in the export of bilirubin and other molecules from the hepatocyte to the bile duct (Fig.
2). Such drugs include androgens (methyltestosterone, retabolil, nerobol) and estrogens (regividon, tricvilar, nonovlon), cytostatics (cyclosporine A), chlorpromazine, sulfonamides, semisynthetic and synthetic penicillins (oxacillin, ampicillin, amoxicillin, carbenicillin, methicillin), macrolides (erythromycin, oleandomycin), cephalosporins (ceftriaxone and ceftazidime), H2histamine receptor blockers (cimetidine, ranitidine), oral hypoglycemic drugs - sulfonylureas (glyburide, gliclazide, glibenclamide) etc.

Side effects of antitumor drugs in patients with Gilbert's syndrome have been described [6]. In patients with Gilbert's syndrome, who received busulfan mode in hematopoietic stem cell transplantation, higher overall mortality and mortality by 200 days after transplantation [21].

Hyperbilirubinemia may often occur with chemotherapy for acute lymphoblastic leukemia. A retrospective analysis showed that 23 out of 159 patients with acute lymphoblastic leukemia had Gilbert's syndrome, these children had higher levels of hyperbilirubinemia with treatment and lower clearance of methotrexate, however, only 5 patients required changes in the treatment regimen as a result. Therefore, the authors do not consider it appropriate to screen for Gilbert's disease in all patients, but if hyperbilirubinemia is detected, appropriate diagnostic tests and changes to the treatment regimen should be performed [3].

It was found that the immunomodulator lenalidomide caused hyperbilirubinemia without activation of alkaline phosphatase, alanine aminotransferase (ALT) and aspartate aminotransferase (AST) in a 55-year-old patient with heterozygous TA7 UGT1A1, the author concluded that the unmasking of Gilbert's syndrome on the background of the use of lenalidomide [27].

It is proposed to apply Hay's law when prescribing lapatinib in patients with Gilbert's syndrome [29]. This law is an empirical rule in case the patient has a high risk of lethal drug-induced liver damage, if the drug causes hepatocellular rather than cholestatic jaundice. The drug causes two to three times the upper limit of ALT or AST,

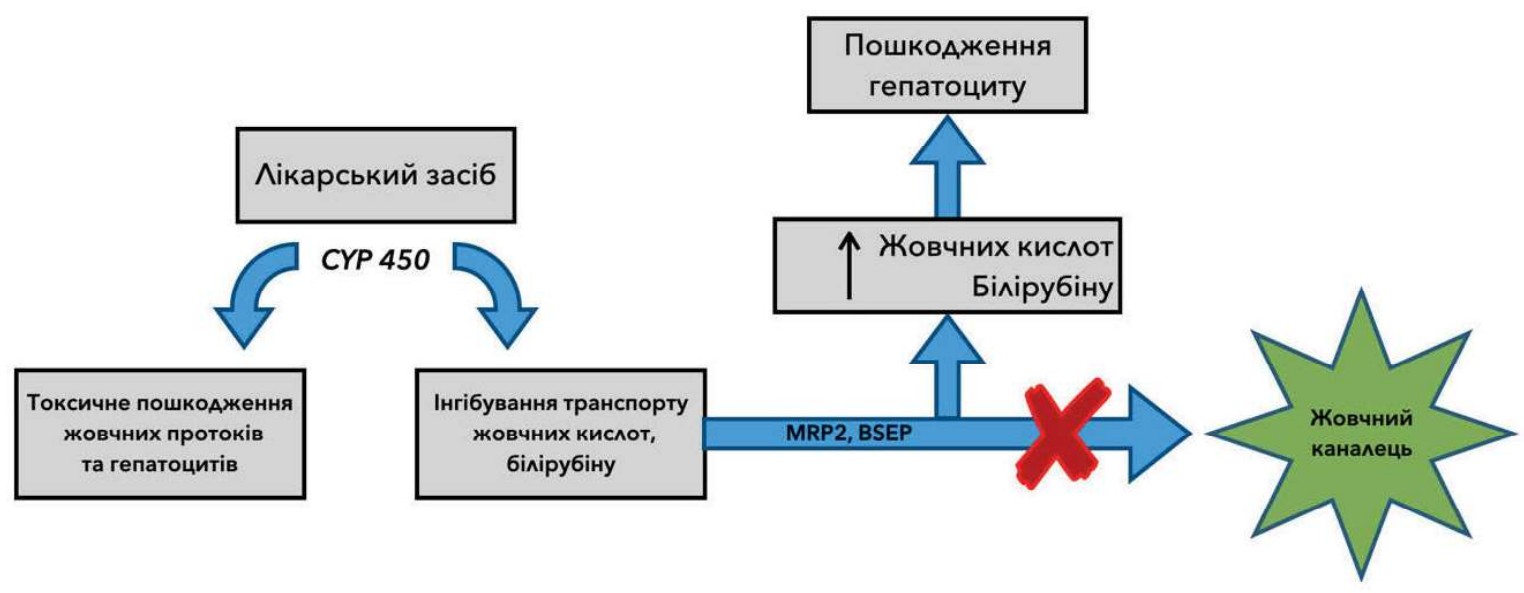

Fig. 2. The scheme of development of cholestasis as a result of the action of medicines 
as well as more than 2 times the upper limit of normal serum bilirubin, without bile stagnation, there are no other reasons for this effect.

It was found that mebendazole - a broad-spectrum antiprotozoal agent, due to impaired glucuronidation caused hepatitis in patients with Gilbert's syndrome [32].

An increase in hepatic transaminases has been reported in a patient with Gilbert's syndrome with depression when taking duloxetine and venlafaxine.Desvenlafaxine did not require participation in the metabolism of the cytochrome P450 isoenzyme 2D6 and did not cause side effects [11].

Antihelicobacter therapy had a negative effect on the glucuronyltransferase system, which led to a violation of the condition in patients with genetic Gilbert's syndrome [4].

No special treatment has been proposed for patients with Gilbert's syndrome. It is proved that isotretinoin (stereoisomer of trans-retinoic acid (tretinoin), which is used to treat acne, significantly reduces blood bilirubin in patients with Gilbert's syndrome in the first 10 weeks of treatment $[12,19]$.

Phenobarbital and other inducers of bilirubin-UGT1 enzymes normalize plasma bilirubin levels in patients with Gilbert's syndrome. This is mainly due to the accelerated clearance of bilirubin due to the induction of enzymes, but also due to a decrease in bilirubin turnover. Steroids may also reduce plasma bilirubin in Gilbert's syndrome by increasing hepatic uptake and storage of bilirubin.

\section{CONCLUSIONS}

Thus, Gilbert's syndrome belongs to common pathological conditions and therefore it is important to diagnose it as early as possible. Considering that the use of aglucones preparations in patients with Gilbert's syndrome can be the cause of the development of medicine-induced liver damage, it is necessary in each case to assess the risk and benefit of medicine treatment for patients with Gilbert's syndrome.

\section{REFERENCES}

1. Ipatova M.G., Shumilov P.V., Shagalova D.L., Nesterova T.A., Ivanova A.S. [Features of pharmacotherapy in patients with Gilbert's syndrome]. Pediatrics. 2015; 94(6): 92-6. [in Russian] URL: https://pediatriajournal. ru/files/upload/mags/349/2015_6_4484.pdf

2. Rejzis, A.R., Hohlova, O.N., Nikitina, T.S. [Gilbert's syndrome. Contemporary views, outcomes and therapy]. Internet Doktor.ru. 2012; 3 (71): 42-5. URL: https://internist.ru/publications/detail/sindromzhilbera.-sovremennye-vozzreniya,-ishody-i-terapiya/

3. Berrueco R., Alonso-Saladrigues A., MartorellSampol L., Català-Temprano A., Ruiz-Llobet A., Toll T., Torrebadell M., Naudó M., Camós M., Rives S. Outcome and toxicities associated to chemotherapy in children with acute lymphoblastic leukemia and Gilbert syndrome. Usefulness of UGT1A1 mutational screening. Pediatr Blood Cancer. 2015 Apr; 62(7): 1195-201. DOI: https://doi.org/10.1002/pbc.25457

4. Botvin'ev K., Kolotilina A.I., Turina, I.E., Dubrovina G.M. [Effect of anti-helicobacter therapy on the hepatic glucuronyl transferase system of adolescents with Gilbert's syndrome]. Klin Med (Mosk). 2014; 92(12), 55-8. [in Russian] https://pubmed.ncbi.nlm.nih. gov/25980300/

5. Buch S., Schafmayer C., Volzke H. et al. Loci from a genome-wide analyses of bilirubin levels are associated with gallstone risk and composition. Gastroenterology. 2010; 139(6): 1942-51. DOI: https://doi.org/10.1053/j. gastro.2010.09.003.

6. Burchell B., Soars M., Monaghan G., Cassidy A., Smith D., Ethell B. Drug-mediated toxicity caused by genetic deficiency of UDP-glucuronosyltransferases. Toxicol Lett. 2000; 112-113: 333-340. DOI: https://doi. org/10.1016/S0378-4274(99)00209-X

7. Dekker D., Dorresteijn M.J., Pijnenburg M., Heemskerk S., Rasing-Hoogveld A., Burger D.M., Wagener F., Smits P. The bilirubin-increasing drug atazanavir improves endothelial function in patients with type 2 diabetes mellitus. Arterioscler Thromb Vasc Biol. 2011 Feb; 31(2): 458-63. DOI: https://doi.org/10.1161/ atvbaha.110.211789

8. Erlinger S., Ariasm I.M., Dhumeaux D. Inherited disorders of bilirubin transport and conjugation: new insights into molecular mechanisms and consequences. Gastroenterology. 2014 Jun; 146(7): 1625-38. DOI: https://doi.org/10.1053/j.gastro.2014.03.047

9. Esteban A., Pérez-Mateo M. Heterogeneity of paracetamol metabolism in Gilbert's syndrome. Eur J Drug Metab Pharmacokinet. 1999; 24(1): 9-13. DOI: 10.1007/BF03190005

10. Farrar J.S., Palais R.A., Wittwer C.T. Snapback primer genotyping of the Gilbert syndrome UGT1A1 (TA)(n) promoter polymorphism by high-resolution melting. Clin Chem. 2011; 57(9): 1303-10. DOI: https://doi. org/10.1373/clinchem.2011.166306

11. Feinberg S. Correction of venlafaxine- and duloxetineinduced transaminase elevations with desvenlafaxine in a patient with Gilbert's syndrome. CNS Spectr. 2010; 15(1): 53-5. DOI: https://doi.org/10.1017/ s1092852900000304

12. Fernández-Crehuet P., Fernández-Crehuet J.F., Allam M.F., Navajas R.F-C. Hepatotoxicity of isotretinoin in patients with acne and Gilbert's syndrome: a comparative study. BMJ Open. 2014; 4(3): e004441. DOI: http://dx.doi.org/10.1136/bmjopen-2013-004441

13. Fretzayas A., Moustaki M., Liapi O., Karpathios T. Gilbert syndrome. Eur J Pediatr. 2012 Jan; 171(1): 115. DOI: https://doi.org/10.1007/s00431-011-1641-0

14. Horsfall L.J., Nazareth I., Pereira S.P., Petersen I. Gilbert's syndrome and the risk of death: a populationbased cohort study. J Gastroenterol Hepatol. 2013; 28(10): 1643-7. DOI: https://doi.org/10.1111/jgh.12279

15. Huang M-J., Chen Y-C., Huang Y-Y., Yang S-S., Chen P-L., Huang C-S. Effect of UDP-glucuronosyltransferase $1 \mathrm{~A} 1$ activity on risk for developing Gilbert's syndrome. 
Kaohsiung J Med Sci. 2019; 35(7): 432-9. DOI: https:// doi.org/10.1002/kjm2.12077

16. Jiang J., Wang H.G., Wu W.L., Peng X.X. Mixed Dubin-Gilbert Syndrome: A Compound Heterozygous Phenotype of Two Novel Variants in ABCC2 Gene. Chin Med J (Engl). 2017 Apr; 130(8): 1003-5. DOI: https://doi.org/10.4103/0366-6999.204108

17. Kabícek P., Barnincová L. Juvenile hyperbilirubinaemia and its early manifestation in adolescence. Cas Lek Cesk. 2007; 146(6): 528-32. PMID: 17650591. URL: https://pubmed.ncbi.nlm.nih.gov/17650591/

18. Kamal S., Abdelhakam S., Ghoraba D., Massoud Y., Aziz K.A., Hassan H., Hafez T., Sallam A.A. The frequency, clinical course, and health related quality of life in adults with Gilbert's syndrome: a longitudinal study. BMC Gastroenterology. 2019; 19. URL: https:// bmcgastroenterol.biomedcentral.com/articles/10.1186/ s12876-019-0931-2

19. Kurtipek G.S., Sar1 N., Akyurek F.T. Significant reduction in bilirubin levels in a patient with Gilbert's Syndrome under isotretinoin treatment for acne vulgaris: A new area of use for isotretinoin? Dermatol Ther. 2019 Mar; 32(3): e12884. DOI: https://doi. org/10.1111/dth.12884

20. Maladaki A., Yavropoulou M.P., Kotsa K., Tranga T., Ventis S., Yovos J.G. Non tumoral hyperserotoninaemia responsive to octreotide due to dual polymorphism in UGT1A1 and UGT1A6. Hormones (Athens). 2012; 11(1): 104-8. doi: 10.1007/BF03401544

21. McDonald G.B., Evans A.T., McCune J.S., Schoch G., Ostrow J.D., Gooley T.A. Mortality outcomes after busulfan-containing conditioning treatment and haemopoietic cell transplantation in patients with Gilbert's syndrome: a retrospective cohort study. Lancet Haematol. 2016; 3(11): e516-e525. DOI: https://doi.org/10.1016/S2352-3026(16)30149-1

22. Nakagawa T., Mure T., YusoffS., OnoE., Harahap I.S.K., Morikawa S. et al. Acetaminophen administration in a patient with Gilbert's syndrome. Pediatr Int. 2012; 54(6): 934-6. DOI: https://doi.org/10.1111/j.1442200X.2012.03602.x

23. Pasha Y.Z., Kacho M.A., Niaki H.A., Tarighati M., Alaee E. The Association between Prolonged Jaundice and TATA Box Dinucleotide Repeats in Gilbert's Syndrome. J Clin Diagn Res. 2017; 11(9): GC05-GC07. DOI: https://doi.org/10.7860/jcdr/2017/19376.10597

24. Radoi V.E., Ursu R.I., Poenaru E., Arsene C., Bohiltea C.L., Bohiltea R. Frequency of the UGT1A1*28 polymorphism in a Romanian cohort of Gilbert syndrome individuals. J Gastrointestin Liver Dis. 2017 Mar; 26(1): 25-8. DOI: https://doi.org/10.15403/ jgld.2014.1121.261.ugt URL: https://pubmed.ncbi. nlm.nih.gov/28338110/

25. Rasool A., Sabir S., Ashlaq M., Farooq U., Khan M.Z., Khan F.Y. Gilbert's syndrome - a concealed adversity for physicians and surgeons. J Ayub Med Coll. 2015; 27(3): 707-10. https://www.sid.ir/en/journal/ ViewPaper.aspx?ID $=561260$

26. Rauchschwalbe S.K., Zühlsdorf M.T., Wensing G., Kuhlmann J. Glucuronidation of acetaminophen is independent of UGT1A1 promotor genotype. Int J Clin Pharmacol Ther. 2004 Feb; 42(2): 73-7. DOI: https:// doi.org/10.5414/cpp42073

27. Simondsen K.A., Kolesar J.M. Lenalidomideinduced elevated bilirubin. J Oncol Pharm Pract. 2012; 18(4): 402-5. DOI: https://doi. org/10.1177\%2F1078155212439492

28. Singh A., Jialal I. Unconjugated hyperbilirubinemia. StatPearls [Internet]. 2020. https://www.ncbi.nlm.nih. gov/books/NBK562172/

29. Spraggs C.F., Parham L.R., Hunt C.M., Dollery C.T. Lapatinib-induced liver injury characterized by class II HLA and Gilbert's syndrome genotypes. Clin Pharmacol Ther. 2012; 91(4): 647-52. DOI: https://doi. org/10.1038/clpt.2011.277

30. Strassburg C.P. Gilbert-Meulengracht's syndrome and pharmacogenetics: is jaundice just the tip of the iceberg? Drug Metab Rev. 2010; 42(1): 168-81. DOI: https://doi.org/10.3109/03602530903209429

31. Strassburg C.P. Pharmacogenetics of Gilbert's syndrome. Pharmacogenomics. 2008; 9(6): 703-15. DOI: https://doi.org/10.2217/14622416.9.6.703

32. Tolomeo M., Colomba C., Meli M., Cascio A. Hepatotoxicity caused by mebendazole in a patient with Gilbert's syndrome. J Clin Pharm Ther. 2019; 44(6): 985-7. DOI: https://doi.org/10.1111/jcpt.13033

33. Vitek L., Bellarosa C., Tiribelli C. Induction of Mild Hyperbilirubinemia: Hype or Real Therapeutic Opportunity? Clin Pharmacol Ther. 2019; 106(3): 56875. DOI: https://doi.org/10.1002/cpt.1341

34. Wagner K-H., Shiels R.G., Lang C.A., Khoei N.S. Bulmer A.C. Diagnostic criteria and contributors to Gilbert's syndrome. Crit Rev Clin Lab Sci. 2018; 55(2): 129-39. DOI: https://doi.org/10.1080/10408363.2018.1 428526

Conflicts of interest: authors have no conflict of interest to declare. Received: 02.12.2020 Revised: 20.12.2020 Accepted: 22.12 .2020

\section{СИНДРОМ ЖИЛЬБЕРА: КЛІНІКО-ФАРМАКОЛОГІЧНІ АСПЕКТИ. ОГЛЯД}

\section{Хайтович М.В., Турчак Д.В.}

\section{Національний медичний університет імені О.О. Богомольия, Київ, Україна nik3061@gmail.com}

Актуальність. На даний момент продовжуться активне вивчення особливостей метаболізму лікарських засобів у пацієнтів із синдромом Жильбера, оскільки з ним може бути пов'язаний як ризик виникнення дозозалежних побічних реакцій, так і неефективності лікування. 
Мета: узагальнити відомості різних авторів щодо особливостей застосування лікарських засобів у пацієнтів із синдромом Жильбера.

Методи. Аналіз наукових публікацій в міжнародній електронній наукометричній базі даних РubМеd за ключовими словами. Глибина пошуку - 10 років (2010-2019 рр.).

Результати. Синдром Жильбера відмічається у 3-10\% населення і характеризується ізольованим підвищенням рівня білірубіну в крові до помірних значень без змін інших біохімічних показників функції печінки та без пошкодження ії структури. Синдром Жильбера успадковується аутосомно-рецесивно і переважно обумовлений наявністю додаткового динуклеотида тимін-аденін (TA) на промоторній ділянці А(TA)6TAA гена, що кодує фермент UGT1A1. Подовження промоторної послідовності призводить до зменшення утворення UGT1A1. При варіанті A(TA)7TAA рівень продукції ферменту може бути знижений до $80 \%$ від норми у гетеро- і до $20 \%$ у гомозигот, відповідно. Синдром Жильбера проявляється підвищенням рівня непрямого білірубіну крові, жовтяницею шкіри і слизових оболонок, болями в животі, а також диспепсією і астеновегетативним синдромом. Інтермітуюча іктеричність склер і шкіри виникає на тлі дії екзо- і ендогенних факторів, таких як голодування, зневоднення, інфекційні захворювання, емоційне і фізичне напруження, гемоліз або менструація, вживання алкоголю, гормональна контрацепція тощо, зазвичай при концентрації білірубіну, що перевищує 40-45 мкмоль/л. Серед ускладнень гіпербілірубінемії при синдромі Жильбера - розвиток жовчокам'яної хвороби, в тому числі - у дітей та підлітків. Синдром Жильбера асоціюється із порушенням метаболізму деяких лікарських засобів - аглюконів. До них відносяться анаболічні стероїди, глюкокортикоїди, андрогени, рифампіцин, циметидин, хлорамфенікол, стрептоміцин, саліцилат натрію, ампіцилін, кофеїн, етиніл-естрадіол, парацетамол, ібупрофен, кетопрофен, сульфаніламіди, діакарб, ментол, кофеїн, статини та ін. Клінічною особливістю синдрому Жильбера є поява або посилення жовтяниці, пов'язаної з прийомом таких лікарських засобів. В умовах дефіциту UGT1 лікарські засоби конкурують з білірубіном за фермент, що веде до підвищення рівня непрямого білірубіну в сироватці крові. Тому для профілактики ураження печінки необхідно в кожному конкретному випадку оцінювати ризик та користь медикаментозного лікування пацієнтів із синдромом Жильбера.

Висновок. Синдром Жильбера відноситься до поширених патологічних станів і тому важливо як можна раніше його діагностувати. Враховуючи, що застосування препаратів-аглюконів у пацієнтів із синдромом Жильбера може бути причиною розвитку медикаментозного ураження печінки, необхідно в кожному конкретному випадку оцінювати ризик та користь медикаментозного лікування пацієнтів із синдромом Жильбера.

Ключові слова: синдром Жильбера, лікарські засоби, метаболізм, фармакогенетика

\title{
СИНДРОМ ЖИЛЬБЕРА: КЛИНИКО-ФАРМАКОЛОГИЧЕСКИЕ АСПЕКТЫ. ОбЗОр
}

\author{
Хайтович Н.В., Турчак Д.В. \\ Начиональный медиџинский университет имени А.А. Богомольиа, Киев, Украина \\ nik3061@gmail.com
}

Актуальность. На данный момент продолжается активное изучение особенностей метаболизма лекарственных средств у пациентов с синдромом Жильбера, поскольку с ним может быть связан как риск возникновения дозозависимых побочных реакций, так и неэффективности лечения.

Цель: обобщить сведения разных авторов относительно особенностей применения лекарственных средств у пациентов с синдромом Жильбера.

Методы. Анализ научных публикаций в международной электронной наукометрической базе данных PubMed по ключевым словам. Глубина поиска - 10 лет (2010-2019 гг.).

Результаты. Синдром Жильбера отмечается у 3-10\% населения и характеризуется изолированным повышением уровня билирубина в крови до умеренных значений без изменений других биохимических показателей функции печени и без повреждения ее структуры. Синдром Жильбера наследуется аутосомно-рецессивно и преимущественно обусловлен наличием дополнительного динуклеотида тимина-аденина (TA) на промоторной области A(TA)6TAA гена, кодирующего фермент UGT1A1. Продление промоторной последовательности приводит к уменьшению образования UGT1A1. При варианте A(TA)7TAA уровень продукции фермента может быть снижен до $80 \%$ от нормы у гетеро- и до $20 \%$ у гомозигот, соответственно. Синдром Жильбера проявляется повышением уровня непрямого билирубина крови, желтухой кожи и слизистых оболочек, болями в животе, а также диспепсией и астеновегетативным синдромом. Интермиттирующая иктеричность склер и кожи возникает на фоне действия экзо- и эндогенных факторов, таких как голодание, обезвоживание, инфекционные заболевания, эмоциональное и физическое напряжение, гемолиз, менструация, употребление алкоголя, гормональная контрацепция и т.п., обычно при концентрации билирубина, превышающей 40-45 мкмоль/л. Среди осложнений гипербилирубинемии при синдроме Жильбера развитие желчекаменной болезни, в том числе -у детей и подростков. Синдром Жильбера ассоциируется с нарушением метаболизма некоторых лекарственных средств - аглюконов. К ним относятся анаболические стероиды, глюкокортикоиды, андрогены, рифампицин, циметидин, хлорамфеникол, стрептомицин, салицилат натрия, ампициллин, кофеин, этинил-эстрадиол, парацетамол, ибупрофен, кетопрофен, сульфаниламиды, диакарб, ментол, кофеин, статины и др. Клинической особенностью синдрома Жильбера является появление или усиление желтухи, связанной с приемом таких лекарственных средств. В условиях дефицита UGT1 лекарственные средства конкурируют с билирубином за фермент, это ведет к повышению уровня непрямого билирубина в сыворотке крови. Поэтому для профилактики поражения печени необходимо в каждом конкретном случае оценивать риск и пользу медикаментозного лечения пациентов с синдромом Жильбера.

Выводы. Синдром Жильбера относится к распространенным патологическим состояниям и поэтому важно как можно раньше его диагностировать. Учитывая, что применение препаратов-аглюконов у пациентов с синдромом Жильбера может быть причиной развития медикаментозного поражения печени, необходимо в каждом конкретном случае оценивать риск и пользу медикаментозного лечения пациентов с синдромом Жильбера.

Ключевые слова: синдром Жильбера, лекарственные средства, метаболизм, фармакогенетика 